\title{
Recent case law
}

\section{Taming the mechanics of mortgage foreclosures: The case of ABSA Bank Ltd $v$ Mokebe and Related Cases 2018 (6) SA 492 (GJ)}

\section{Introduction}

The issue of foreclosures has for a while now, been of immense public interest (see e.g. Brits "The "reinstatement" of credit agreements: Remarks in response to the 2014 amendment of section 129(3)-(4) of the National Credit Act" 2015 Dejure 5; Sham "Executed in execution: discussion and suggestions regarding the immovable property foreclosure process in South Africa" Available at https://researchspace. ukzn.ac.za/xmlui/bitstream/handle/10413/15030/Sham_Nikhil_2017. pdf? sequence $=1$ \&isAllowed $=y)$ ). It is a well-known subject and only needs a brief recital. To put that assertion into perspective, it is reported that South Africa has historically been characterised as having one of the most uncompromising, aggressive and highest number of executions against homes in the world (Shaw "Too quick to execute - how does SA's new rules on sale in execution compare internationally?" 2016 De Rebus). Traumatic anecdotal evidence from the media and decided cases points to an unfair system which for many decades now - aided by judicial indecision and want of legislative intervention - has led to bourgeoning numbers of foreclosure applications and subsequent home losses (see e.g. Chemwi Evictions in South Africa Community Law Centre; Truter "Evictions - a sad reality in South Africa" 2016 De Rebus 30). For instance, the Local Division of the High Court in Johannesburg railed that it "has had to adjudicate the substantial rise in foreclosure applications. These applications have at times exceeded hundreds per week' (Absa Bank Limited v Lekuku (32700/2013) [2014] ZAGPJHC 244 (14 October 2014) at Para 9). The chaotic regime through which these repossessions were undertaken engendered reservations about the possibility of collusion between banks and 'bargain hunters.' It was associated with an environment where primary residences of financially distressed people were auctioned for unreasonable amounts and in circumstances, which were manifestly irreconcilable with the debtor's constitutional rights.

On 2 May 2018, the Judge President issued a directive in terms of section 14(1)(a) of the Superior Courts Act through which he ordered a full Bench of the High Court to deliberate on the issue of home repossession judgments and to prescribe procedures that have to be complied with in cases where execution of judgment is sought. This was a salutary attempt to bring sanity to what had emerged to be a muddle of inconsistent judgments.

How to cite: Kawadza 'Taming the mechanics of mortgage foreclosures: The case of ABSA Bank Ltd v Mokebe and Related Cases 2018 (6) SA 492 (GJ)' 2019 De Jure Law Journal 102-109 http://dx.doi.org/10.17159/2225-7160/2019/v52a6 
From the vantage point of the land mark case of Absa Bank Ltd $v$ Mokebe and Related Cases 2018 (6) SA 492 (GJ) (herein after 'Mokebe'), this case note seeks to discuss the intervention introduced to bring the issue of foreclosures within the parameters of the Constitution and related socio-economic rights jurisprudence.

\section{Facts}

In terms of section 14(1)(a) of the Superior Courts Act 10 of 2013, a full bench of the High Court was assigned to make a ruling on the procedures that banks have to follow when foreclosing mortgages on primary residences as well to pronounce on the correctness of the practice of the courts of granting applications for money judgments against judgment debtors (defaulting homeowners) while postponing the associated applications for sale in execution. Equally, the High Court was tasked to consider when it would be appropriate for the courts to set a reserve price for the hypothecated property in terms of rule 46A (8) (e) of the Uniform Rules of Court.

Having considered the applicable statutory provisions such as section 26 of the Constitution of South Africa, 1996 (which guarantees the right to adequate housing) and section 129(4) of the National Credit Act 34 of 2005 (which provides that reinstatement of a credit agreement is no longer possible after the sale of property pursuant to an attachment). The court held that in all cases where the debtor's primary residence was subject to execution the entire claim, including the money judgment, had to be adjudicated at the same time. If there was a need for postponement, it had to be postponed in its entirety.

Further, the court ruled that in terms of section 129(3) of the National Credit Act, until the proceeds of the auction sale have been realised the judgment debtor, despite the existence of a money judgment and order for executability, could still resuscitate the mortgage contract by paying the outstanding amounts. More importantly, it was held that except in exceptional circumstances, the court was bound to set a reserve price in all cases where execution was granted against the primary residence of the mortgagor. The court reiterated that reserve price was crucial in balancing the misalignment between the banks and the debtors where execution orders are granted. More specifically, a reserve price would ensure that the defaulting homeowner does not suffer prejudice arising from the low prices accepted at sales in execution. It was further stated that the mortgagor and applicant for execution have an obligation to set relevant facts with regard to Rule 46A of the Uniform Rules of Court to enable the court to properly exercise its discretion appropriately.

\section{Discussion}

To better understand the public and media frenzy exulting Mokebe, one needs to consider the context within which the new dispensation comes from. It should be understood that until recently Rule 46 of the Uniform 
Rules of Court and Rule 43 of the Magistrates' Court Rules, have always permitted the sale of the judgment debtor's property in execution to the highest bidder without a reserve price.

Ownership of a residence has always served several social objectives in South Africa. As such, the inherent arbitrary deprivation of immovable properties through executions has been seen as a threat to the attainment of basic human socio-economic rights as provided in the Constitution of South Africa (Brits; Sham supra). As such, there is recognition that foreclosures should not be dealt with solely as ordinary commercial matters (see e.g. Moneyweb "Calls for inquiry into home and car repossession abuses" (2017-12-1); South African Human Rights Commission "Report on the Public Hearing on Housing, Evictions and Repossessions" at https://www.sahrc.org.za/home/21/files/Reports/ Housing\% 20Inquiry\% 20Report_2008\%20web.pdf). More specifically, there is an acknowledgment that selling one's property for a price lower than its real value constitutes an arbitrary deprivation of one's property in contravention of to section 25 (1) of the Constitution which provides that no one may be deprived of property 'except in terms of law of general application, and no law may permit arbitrary deprivation of property.'

Furthermore, section 26 states that:

(1) Everyone has the right to have access to adequate housing.

(2) The state must take reasonable legislative and other measures, within its available resources, to achieve the progressive realization of this right.

(3) No one may be evicted from their home, or have their home demolished, without an order of court made after considering all the relevant circumstances. No legislation may permit arbitrary evictions.

In essence therefore, 'access to adequate housing is linked to dignity and self-worth' (Mogkoro J in Jaftha v Schoeman 2005 (2) SA 140 (CC) para 27). In the same manner, research has shown that homeownership is associated with greater control and better responsibility over people's living environment. Additionally, it is said to secure neighbourhoods and strengthen communities (Baum and Kingston "Homeownership and social attachment" 1984 Sociological Perspectives 27 159; DiPasquale and Glaeser "Incentives and social capital: Are homeowners better citizens?" 1999 Journal of Urban Economics 354).

Despite that, more than 100000 homes were repossessed in South Africa since 1994 (Ryan "SA banks sued for R60bn in home repossession case" available at https://www.fin24.com/Companies/Financial-Services/ r60bn-home-repossession-suit-against-banks-20170816). Furthermore, "the 10 year period between 2006 to 2015 statistics show that 112,325 properties in South Africa were sold in execution - over 11000 a year. This is exponentially higher than both the United States of America and the United Kingdom over the same period of time" (Sham supra at 7). 
The inequitableness of the process has seen houses being sold for a pittance. For instance, a house worth R470 000 was sold for R40 000 to settle a debt of R370 000 (Nkwane $v$ Nkwane and Others (36700/2016) [2018] ZAGPPHC 153 (22 March 2018). Politicians have been quick to notice the public's condemnation of the perceived mercantilist approach and have openly fed the frenzy of public disapproval. Government has labelled the manic style through which sales in execution have been undertaken as amounting not only to subversion of the country's transformation agenda, but is also a setback to social justice and the right of access to housing (see e.g. Nzimande "We must transform banks and fight financialisation" Politics Web (2015-10-4); Moneyweb "Calls for inquiry into home and car repossession abuses" (2017-12-11); South African Human Rights Commission "Report on the Public Hearing on Housing, Evictions and Repossessions" at https://www.sahrc.org.za/ home/21/files/Reports/Housing \% 20Inquiry\% 20Report_2008\%20web. pdf). One cabinet minister deplored the level of evictions as:

Comparable to apartheid-era group areas removals. The homes are then sold at auction, very often at a fraction of their market value. The worst-case scenario involved a house sold at R10, and a house taken away for nothing but corruption involving the concoction of title deeds; the owner was dispossessed and jailed for a while. All this is inhuman (Ground up 'Residents fight back against banks' eviction tactics' at https://www.groundup.org.za/ article/residents-fight-back-against-banks-eviction-tactics_3572).

The deluge of home losses came on the backdrop of rising homelessness in the country. Reports indicate that despite extensive government efforts to deliver affordable housing through initiatives such Reconstruction and Development Programme (RDP) houses and the National Housing Subsidy Programme. The housing backlog still remains very high with around 12 million people lacking decent accommodation and an estimated $1.5 \mathrm{~m}$ households living in slums ("Housing Finance in Africa: A review of some of Africa's housing finance markets" at http:// housingfinanceafrica.org/app/uploads/CAHF_Housing-Finance-in-AfricaYearbook-2016.09.pdf; Affordable Housing in Africa: A fact or a Fiction? Available at https://housingfinanceafrica.org/app/uploads/olivier-vidalpresentation-Cape-town-July-2017-.pdf). Several challenges have been cited, suffice to say that untrammeled foreclosures have been a contributory factor. The majority of the evicted defaulters have ended up in shantytowns with limited chances of reintegration into the economy (Sibiya 'The case against banks' abusive home repossession practices' at https://www.iol.co.za/capetimes/opinion/the-case-against-banks-abusive -home-repossession-practices-11267091).

The judiciary has not been oblivious to the systemic losses of homes through repossessions. Despite that, several judges recognised the legality of and endorsed sales in execution without reserve price as provided by Rule 46(12) of the Uniform Rules of Court. For instance, Mouton $v$ ABSA (Case number 17922/2014) and Haylock $v$ ABSA (Case number 24820/2015) restated that Rule 46(12) did not amount to an indefensible curtailment of the debtor's right to adequate housing. The 
same was adopted in Bartezky and Another $v$ Standard Bank of South Africa Limited and Others [2017] ZAWCHC 9 of 16 February 2017.

Besides justifying repossessions on the practical expediency, other members of the judiciary based their decisions on economic considerations, arguing that repossessions and subsequent flogging of properties are a facilitative mechanism for the health of mortgage industry and as such is paradoxically a beneficial aspect of the home ownership cause (see e.g. Mouton $v$ Absa supra at 11; Nkwane $v$ Nkwane and Others para 23; Standard Bank of South Africa Ltd $v$ Saunderson and Others 20062 SA 264 (SCA); Nedbank Ltd $v$ Fraser and Another and Four Other Cases 20114 SA 363). It is such decisions that have been associated with a perception that the judiciary is obstructive or tend to frustrate reinstatements of mortgage agreements.

Fortunately, and in a way that demonstrates inconsistency and lack of unanimity on the bench, the debtor-unfriendly style was not replicated in other cases. Some judges have demonstrated exasperation with, and openly vilified the disproportionate processes associated with most of the applications for repossessions. For instance, in ABSA Bank $v$ Ntsane (2007 (3) SA 554 (T)) Bertlesman J found it unjust and unequitable to authorise execution against a debtor when the arrears in issue were a measly R18.46. Similarly, in FirstRand Bank Ltd v Maleka (2010 (1) SA 143 GSJ), CJ Claassen refused foreclosure where the arrears were low. In a clear departure from the reasoning in cases such as Mouton $v$ Absa and Nkwane $v$ Nkwane and Others, the court stressed that:

[W] henever a bondholder calls up the bond, or seeks an order declaring the bonded property specially executable, while the amount in arrears at date of application for judgment is so small that it should readily be capable of settlement by execution against movable assets, taking all circumstances into account, the declaration of the immovable property as executable would constitute an infringement of the debtor's fundamental right to adequate housing (ABSA Bank Ltd $v$ Ntsane and Another (2007 3 SA 554 (T) para 86)).

There was a realisation that the outstanding amount could be too low to justify the taking of the person's primary residence. Likewise, some courts also considered whether the benefit to be gained by the creditor outweighs the prejudice suffered by the debtor. As such, some judges adopted a more pragmatic and sympathetic route and refused to grant an execution and instead suggested that the debtor be given an opportunity to explore other means of settling the arrears. Execution was to be the last resort. In FirstRand Bank Ltd t/a First National Bank v Seyffert and Another). Similarly, in another case the court refused to grant an execution and recommended that the creditor pursue other less injurious and "less invasive" means to satisfy the debt. "[W]here it is sought, an order that has the potential of encroaching drastically upon the fundamental rights of a person, the applicant who seeks such an order, must first exhaust other less invasive remedies before resorting to a cause that is much more invasive" (Standard Bank of South Africa $v$ 

2011)).

That narrative is arguably an eloquent demonstration of the disarray on the bench in as far as the issue of repossessions is concerned. Largescale legal uncertainty and inconsistency resulted in absurd, prejudicial and manifestly unconstitutional outcomes (see e.g. "Assessment of the Impact of Decisions of the Constitutional Court and Supreme Court of Appeal on the Transformation of Society Final Report" at http:// www.justice.gov.za/reportfiles/2017-CJPreport-Nov2015.pdf). Equally damaging is that the "dignity of the court is bound to suffer irreparable harm if every one of the ... judges can go his own merry way (Trade Fairs and Promotions (Pty) Ltd $v$ Thomson \& Another (1984 (4) SA 177(W) at 187)).

It was also observed that "despite a number of landmark judgments confirming the state's obligation to take reasonable measures to ensure the progressive realization of socio-economic rights, the apex courts always adopted a constrained approach when adjudicating on disputes involving socio-economic rights" (Final Report "Assessment of the Impact of Decisions of the Constitutional Court and Supreme Court of Appeal on the Transformation of Society" at ii. Available http:// www.justice.gov.za/reportfiles/2017-CJPreport-Nov2015-Final.pdf). So extensive was the disparity in how these cases were to be disposed of that Van der Linde J implored for "even relevant obiter dictum from a full court [to] provide guidance in an area where currently individual judges' approached are so inconsistent" (Absa Bank v Mokebe et al Case number: 2018/00612 footnote 19).

In self-justification, courts countered the public denunciation on the basis that "these differences of opinion are not the kind of issues courts should interfere with too readily. They are mostly instances of legislative facts where courts should not easily interfere with the choices made by legislatures" (Shoprite Checkers (Pty) Limited v Member of the Executive Council for Economic Development, Environmental Affairs and Tourism, Eastern Cape and Others (2015 (6) SA 125 (CC)). On the unfairness of the debtor losing equity through the absence of reserve price, it was contended that "a mandatory reserve price is a policy matter that must be left to the legislature" (Nkwane $v$ Nkwane and Others at para 18).

Furthermore, until the 2010 amendment to High Court Rule 46(1)(a)(ii) there was no judicial control over the whole process of execution as the registrar and the courts had the prerogative to grant executions. Judges had resigned to the reality that the whole process was an 'executive matter which is dealt with by the Registrar' (Gerber $v$ Stolze and Others (251951 (2) SA 166 at 171E)). Much as the amendment to High Court Rule sought to align executions in line with the Constitution, it did not assist as anticipated as it still allowed for repossessions as long as the property was declared executable. 
What makes Mokebe laudable is that it has not only reinforced transformative constitutionalism in the form of the right to access to adequate housing but has also ushered the much needed clarity and judicial comity to the issue of repossessions. It is hoped that the dispensation will bring to an end the public distrust in the judiciary as well as the elimination of unfair home repossessions.

Much as the court is not obliged to set a reserve price but to consider the factors under Rule 46A(9)(9b) of the Uniform Rules of Court when making a determination, the existence of the mechanism upon which a determination for a reserve price can be made is a commendable one. Furthermore, Mokebe reinforces judicial oversight regarding the executability of the judgment debtor's primary residence. Equally noteworthy is that it does away with the previous environment, which was characterised by a "misalignment of incentives" and provided fertile ground upon which syndicates managed to buy properties for cheap and resold them at higher prices. More specifically:

There are benefits in setting a reserve price. Doing so prevents or inhabits fraud and collusion intended to keep the sale price low. A reserve price will also account for the misalignment in the incentives between creditor and debtor: Banks seeks to recover the amount owing plus costs and nothing more, any amount in excess of all this will only be to the debtor's benefit. Whereas, the debtor seeks to obtain the maximum sale price. Therefore, the bank has no incentive in realizing the full price (Standard Bank of South Africa Limited $v$ Hendricks and Another Western Cape High Court 11294/18 at para 59).

Additionally, a "reserve price enables the former house owner to realise equity from the home. Likewise, it would assist in avoiding or minimising a deficiency in the judgment" (see e.g. Hughes "Taking personal responsibility: A different view of mortgage anti-deficiency and redemption statutes" 1997 Ariz. L. Rev. 124). As such, the "introduction of a requirement that a sale in execution ... be subject to a market value related reserve price might have some societal value" (Binns-Ward J in Ricardo Baretzky Anor $v$ Standard Bank Of South Africa Limited and Others High Court Of South Africa (Western Cape Division, Cape Town) Case No. $13668 / 2016$ at para 14).

Over and above these justifications, judicial intervention has the beneficial effect of minimising the unequal bargaining power and related information asymmetry associated with foreclosures. It has been shown that in a foreclosure 'the bank is likely to have superior information about the quality of the property, since lenders typically spend significant resources on appraisals to get a more precise value of the collateral before granting mortgages' (Niedermayer, Shneyerov and Xu "Foreclosure Auctions" Discussion Paper No. 522 at 2. See also Absa Bank Limited v Lekuku at para 29). 


\section{Conclusion}

By empowering courts to postpone execution applications to allow customers time to pay arrears, this ruling gives much needed relief to judgment debtors. Until Mokebe, the issue of the executability of a primary residence had come to one crossroads and turned left, that is to the path of mercantilist considerations and banking sector expedience. Mokebe has changed that and in many ways, the borrower-protective provisions have yielded a positive change. It has injected a measure of consistency, uniformity and has marshaled the South African home ownership terrain firmly within constitutional rights. More importantly, Mokebe has arguably moved the foreclosure process from merely being an act of balancing the competing interests of the parties to a mortgage dispute and elevated it to a level where that process reflects broader public interests in housing policy. It has also brought the South African approach in conformity with international trends and more specifically, to mirror approaches in France, Ghana and Germany, Malaysia and Korea where banks are enjoined to sell repossessed homes at fair market value.

HERBERT KAWADZA

Senior Lecturer, University of Witwatersrand 